\title{
Business Opportunities and Market Realities in Financial Conglomerates
}

\author{
Sotiris K. Staikouras \\ Risk Institute \& Emerging Markets Group, Cass Business School, City University, 106 Bunhill Row, \\ London EC1Y 8TZ, U.K. \\ E-mail: sks@city.ac.uk
}

The Financial Services Act of 1986 prompted changes to remove the regulatory hedges among financial institutions. The present work sets out to explore the non-quantitative aspects of the interface between banks and insurance firms. Without discounting any quantitative analysis, the study diverts from the existing literature by placing equal weight to the so far overlooked qualitative elements. The paper reviews the various market trends and highlights the differences among major European countries. The diverse and inconclusive bancassurance literature is also briefly reviewed. Having discussed the cultural differences and integration obstacles between banks and insurance firms, the study proposes a three-dimensional radar-shape approach for the financial conglomerate. More specifically, product complexity, distribution infrastructure and market integration are put forward as the forcing variables underlying the provision platform of modern hybrid financial services. The analysis further elaborates on a number of market-based synthetic corporate structures drawn from the European experience as a whole. Finally, two broad drivers - exogenous (market) and idiosyncratic (operational and strategic) - along with their constituents, mainly held responsible for the success/risk of the new universal financial intermediary, are identified and analysed. The paper concludes by summarizing the main issues and pointing to avenues for potential research.

The Geneva Papers (2006) 31, 124-148. doi:10.1057/palgrave.gpp.2510060

Keywords: financial institutions; bancassurance; financial conglomerates; universal banks

JEL classification: G15; G21; G22

\section{Introduction}

At the onset of the 21st century, insurance markets in Europe are evolving in an unprecedented manner. After years spent locked in the regulatory battle over whether bankers should be allowed to make inroads into the insurance business, the two institutions are now experiencing the forms of interface that market practices copiously offer. It has come as a result of cross-border consolidation and their lust for mounting ownership's benefits. More and more intermediaries are now expanding their operations beyond their immediate national or local geographical borders (the frequency of the trend being irrepressible), resulting in mega-mergers, financial conglomerates and universal banks. ${ }^{1}$ The motive underneath remains the same:

\footnotetext{
${ }^{1}$ Institutions that offer a wide range of financial services are categorized as financial conglomerates, while universal banks are usually corporations that control both financial and non-financial business entities.
} 
pursuing new business opportunities and/or a taste of new profitable financial structures. The phenomenon falls under the umbrella of the convergence in the financial services industry, with the bancassurance term being more widely used. The term first appeared in France, in the early 1980s, and variants of it are also known as Assurancebank or Allfinanz. Financial services naturally encapsulate activities ranging from simple financial advice to complex risk management operations. In the case of financial convergence, the synthetic financial intermediary (or synthetic corporate structure) would espouse a large chunk of these diverse activities. Van den Berghe ${ }^{2}$ explores the matter in the context of financial conglomerates and the issues surrounding them, while Merton $^{3}$ discusses the problem in view of a functional approach to finance and insurance and provides clues to understanding the trend as natural.

Although various definitions are available, the notion of bancassurance is essentially the provision of financial- and insurance-related products through a single corporate provider. The phenomenon, however, has taken various forms over the years, such as provision of services by different subsidiaries of the same holding company, often using different channels, or embracing alliances of two separate business entities aiming to sell each other's products. In 1992, Swiss Re offered a broad definition: "As a rule, bancassurance can be described as a strategy adopted by banks or insurance companies aiming to operate the financial services market in a more or less integrated manner. In practice, the term 'bancassurance' is consistently used to describe a new strategic orientation of financial institutions in private customer basis". One year later, Chatillon, the president of the French Association for Credit Institutions, defined it as "a business strategy - mostly initiated by banks - that aims at associating banking and insurance activities within the same group, with a view to offer these services to common customers who, today, are mainly personal customers". The above definitions show the multiple forms in which the phenomenon can appear.

But what is the landscape of the financial services industry in Europe? Is there any theoretical or empirical evidence in favour of or against the phenomenon? Are there any theoretical or practical models indicating the exact structure of a successful interface? What are the possible risk-success drivers behind the creation of such hybrid corporate structure? Last but not the least, what does the future actually hold for the newcomer in modern financial markets? These are all questions that the present work aims to address along with stimulating further debates on this topic. The current study deviates from the existing literature as it examines and discusses the qualitative aspects of the convergence in financial institutions. These aspects have been overlooked in the existing literature as very few studies ${ }^{4}$ have paid attention to them.

The paper sets out to analyse such market realities from a strategic perspective and provide further insight. Despite the importance of quantitative modelling and the

\footnotetext{
${ }^{2}$ Van den Berghe (1998).

${ }^{3}$ Merton (1994).

${ }^{4}$ Santomero (1989); Herring and Santomero (1990); Dickinson (1993); Bergendahl (1995); Van den Berghe and Verweire (1998); Van den Berghe, Verweire and Carchon (1999); Santomero and Eckles (2000).
} 
number of studies concentrating on it, synthetic corporate structures are far more complex to be analysed simply along these lines, and subsequent strategic decisions should not be made based purely on quantitative techniques. Previous empirical work ${ }^{5}$ sheds light only on the measurable dimensions of the phenomenon. On the other hand, there are various risks and other attributes - reputation, cultural, legal, structural, operational, etc. - which are not easily quantified but equally important to be carefully considered. Thus, the current work delves into these issues and proposes a radar-shape approach to better understand the bancassurance distribution/promotion platform. It also examines the individual building blocks within that network and explores the main corporate structures surfacing in Europe. Finally, the study identifies the possible risk-success corporate drivers underpinning hybrid financial institutions, which in turn could contribute towards a functional and viable corporate structure. For this purpose, Europe offers an ideal landscape as financial conglomerates are permitted by the Second Banking Directive of 1989, which has been implemented by all member states.

In what follows, the next section reviews the recent trends in Europe and brief comparisons are made with other continents. The following section overviews the empirical evidence related to the abandonment of the regulatory parapet between the two industries. The following section presents a multi-layer approach of the distribution/promotion network and discusses the cultural differences of the two industries. The penultimate section analyses the core market-based models of bancassurance and looks closely at the factors that could enhance the viability of the phenomenon. Finally, the last section concludes and looks at possible topics for further research.

\section{Market practices across Europe}

Over the last two decades, the bancassurance phenomenon made its presence felt in Europe with alliances between banks and insurance groups. This has concentrated the bancassurance market, which was originally highly fragmented. The "new" synthetic form of financial services has become widely recognized as a successful model in markets such as France, Spain and Portugal, followed by Italy and Belgium. It represents over 65 per cent of the premium income in life insurance in Spain, over 60 per cent in France and Italy and over 50 per cent in Belgium. In some European countries, the bank penetration exceeds a rate of 50 per cent, while the U.K. and Germany have opted for more traditional networks.

The French life insurance market enjoys a big share in both European and global financial markets. Even as early as 1988, insurance subsidiaries of banks controlled a large proportion of the new life insurance production in France. Here, the phenomenon is primarily tax driven: some tax-advantaged insurance products are only available through banks. Over the last two decades, many banks have created

\footnotetext{
${ }^{5}$ Brewer (1989); Santomero and Chung (1992); Boyd, Graham and Hewitt (1993); Saunders and Walters (1994); Eisenbeis (1995); Brown, Genetay and Molyneux (1996); Gande, Puri and Saunders (1999); Lown et al. (2000); Carow (2001a, b); Nurullah and Staikouras (2004).
} 
their own life insurance subsidiaries, and now there is not a single bank of a given size that does not have its insurance subsidiary for life products. In 2000, bancassurance accounted for 35 per cent and 60 per cent of life insurance and savings premiums, respectively, 7 per cent for property insurance and 69 per cent of new premium income in individual savings. France has overtaken the U.K. and German markets, largely due to the development of distribution channels through banks. More recently, some banks have diversified into property and casualty $(\mathrm{P} \& \mathrm{C})$ insurance. ${ }^{6}$ Today, new production of $\mathrm{P} \& \mathrm{C}$ is largely driven by bank subsidiaries, which are set to take a much larger part in writing personal insurance and usually exclude motor insurance.

Bancassurance in Italy, Spain and Belgium has been characterized by rapid growth. In Spain, the phenomenon has developed swiftly because of the well-established network of regional building societies, which today accounts for 50 per cent of life insurance premiums in the bancassurance sector. It represented over 65 per cent of life insurance premium income in 2001 (approximately $€ 17$ billion), compared with 43 per cent in 1992. ${ }^{7}$ Portugal has recorded the highest penetration rate in bancassurance, with 82 per cent of the market share, but it only represents approximately $€ 4$ billion in premiums on a limited life insurance market. The 1990 Amato Law, ${ }^{8}$ coupled with the favourable tax environment (1995-1998), launched bancassurance and further promoted life insurance products in Italy. The substantial banking network combined with the Italian public's trust in banks contributed to the development of this phenomenon. As a result, bancassurers' share of the market increased from 8 per cent in 1992 to 50 per cent in 2002, representing over 60 per cent of new life insurance business and including more than 70 per cent of savings products. Bankers and insurers have been brought closely together partly by the increasing trend of mergers, acquisitions and corporate restructuring. ${ }^{9}$ In Belgium, bancassurance has dominated 56 per cent of the market share in life insurance products, becoming the leading distribution network, while the five market leaders are members of bank or insurance groups.

At this stage, it is also worth mentioning that most players recognize that the biggest untapped bancassurance opportunity is life insurance. The latter is currently distributed through expensive agent sales forces and has yet to be purchased by many potential consumers. Thus, the question for both banks and life insurers is how to organize themselves to profit from this new opportunity. The answer might possibly lie in forming partnerships and business alliances. Figure 1 shows some results relating to the distribution networks in the European region.

Despite the fact that bancassurance has been predominantly a European concept, it has also been growing in other countries, especially in emerging economies, where the insurance and banking sectors are still evolving. Since the mid-1990s, cross-border

\footnotetext{
${ }^{6}$ The overlap in the two businesses is even more apparent in modern capital markets, where products extensively used by banks, such as credit-default swaps, closely resemble a casualty insurance policy, albeit without either an insurable-interest requirement or any role for an insurance adjuster.

${ }^{7}$ This high growth rate is not specifically due to bancassurance, but rather the whole of the life insurance market, which has sustained a 30 per cent increase per annum on average in the past 15 years.

${ }^{8}$ The Amato Law allows banks to own shares in insurance companies.

${ }^{9}$ Sudarsanam (1995).
} 


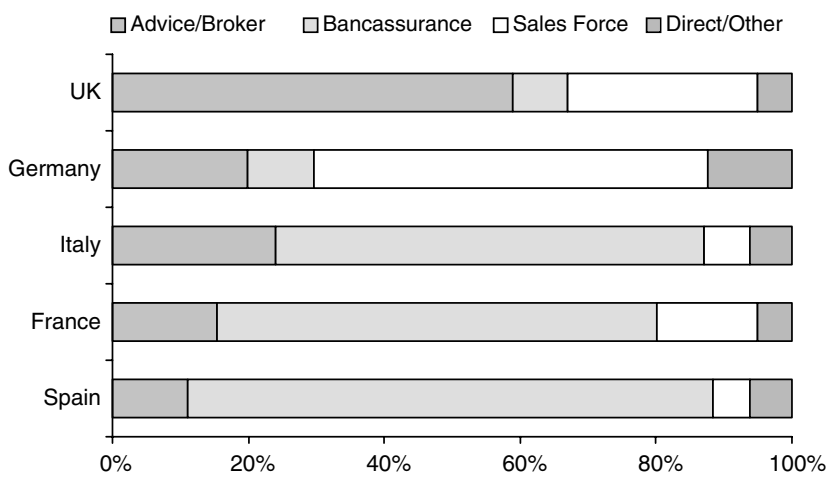

Figure 1. Life distribution networks in Europe.

links between banks and insurance companies have also become more common with foreign insurers taking shares in local banks (Aegon's joint venture with Mexican bank Banamex in 1995), or vice versa. In Brazil, five out of the eight largest insurance groups belong to banks, and in Mexico, 16 out of a total of 64 insurers belong to a financial group. In Singapore, bancassurance claims a market share of 24 per cent of new business in the life insurance sector, while Malaysia and Thailand claim 6 per cent and 2 per cent, respectively. Furthermore, Japanese (April 2001) and Korean (August 2003) banks are the newcomers in this market. The phenomenon is also well developed in Australia. The Australian Prudential Regulatory Authority was formed in 1998 following the Wallis Committee's 1997 report. It is worth noting that banks, which also have 56 per cent of all premiums, own 43 per cent of assets in the Australian life insurance sector.

Conversely, the Glass-Steagall Banking Act of 1933 slowed down the phenomenon in the U.S. Before the Congressional passage of the 1999 Financial Services Modernization Act (FSMA), ${ }^{10}$ which repealed the Glass-Steagall Act and the Bank Holding Company (BHC) Act (1956), significant restrictions existed upon the affiliation of banks with securities firms, as well as on the direct conduct by banks of securities dealing, underwriting and related securities activities. In addition, with certain narrow exceptions, banks were prohibited from engaging in insurance activities or affiliating with insurers. ${ }^{11}$ The Act removes these remaining barriers by allowing

${ }^{10}$ The FSMA is also known as the Gramm-Leach-Bliley Act. The interested reader is referred to Saunders and Cornett (2005) for a discussion regarding the major U.S. laws.

${ }^{11}$ The National Banking Act of 1918 authorizes national banks to sell insurance from banks located in a town with a population of less than 5,000 or sell insurance products that are "necessary to carry on the business of banking". For presentation of how these laws have been interpreted by the Office of the Comptroller of the Currency and the Supreme Court, see Carow (2001a, b). Moreover, in a number of U.S. states, mutual savings banks were allowed to underwrite and market life insurance. Note that the current dual banking system allows both states and the federal government to issue bank charters. Thus, instead of seeking a national charter, banks can be chartered by any of 50 individual state bank regulatory agencies. For an excellent discussion and more information regarding the management of financial intermediaries, see Saunders and Cornett (2005). 
banks to affiliate with securities firms and insurers, through a holding company structure, as well as permitting nationally chartered banks to engage in most financial activities through direct subsidiaries. Under the FSMA, the cross-ownership of banks, securities firms and insurance companies is now possible, as is the conduct of commercial banking, investment banking, merchant banking, investment management, securities underwriting and insurance within a single financial institution. There are very few partnerships, however, between bankers and insurers apart from creditor insurance. Moreover, the fact that they do not share the same information system does not facilitate any rapid development. The U.S. Congress is promoting and encouraging the hybrid portfolio under the same holding company - a step that the major trade associations embrace, while recognizing that many details must still be worked out. Even though hundreds of financial holding companies have been approved by the Federal Reserve, no U.S. financial services groups other than Citigroup $^{12}$ obtained such status over the last decade.

Unlike many other countries in Europe, the U.K. life insurance market is to a large degree in the hands of the brokers - independent financial advisers who account for around half of the new life and pension business. For many years, banks were distributing insurance products without being allowed to write insurance. Until the mid-1980s, banks were not authorized to control insurance firms. Soon after, the provisions in the Financial Services Act of 1986, which radically changed the insurance distribution through independent agents, prompted some changes. These changes finally allowed banks to market all types of insurance products and to set up insurance subsidiaries. At the same time, many life insurance mutuals are demutualizing and are getting closer to banks. Europe's bancassurance has grown quicker than Britain's. In 1999, the U.K.'s share of life and pensions new premium income was 9.3 per cent compared with over 60 per cent in Italy, France or Spain. In addition, cultural differences in the pensions industry make the U.K. market much bigger than the French. ${ }^{13}$ One could argue that besides the less tax-advantageous environment in the U.K., the complexity of the U.K. life and pensions market has made the phenomenon less of a success story.

Today, new developments are taking place, especially with the building societies, which are in the process of setting up their own insurance subsidiaries. Post-CP121 and the findings of the Sandler and Pickering reports, ${ }^{14}$ U.K. insurers will face

12 Citigroup is a very interesting case since, on 20 August 2002, it spun off the property and casualty division of Travelers, which was later merged with St. Paul Cos. On 31 January 2005, Citigroup sold its Travelers life insurance and annuity business to the U.S. insurer MetLife for $\$ 11.5$ billion. The deal includes an agreement that allows MetLife to distribute its products through Citigroup businesses worldwide. The deal completes the jettisoning of the Travelers business, which Citigroup acquired almost 7 years ago.

${ }^{13}$ There is a big pensions industry in the U.K., which does not exist in France, where pensions are still paid by the state.

${ }^{14}$ In January 2002, the FSA published the "Reforming Polarisation: Making the market work for consumers, Consultation Paper (CP121)" document, which seeks ways of differentiating regulatory requirements to reflect the lower risk profile of certain investment products. The FSA proposes two significant reforms in CP121: (a) the creation of a new type of adviser, a distributor or multi-tie, who can offer products from a panel of product providers, and (b) the replacement of the commission-based 
increasing competition from banks. The cooperation may be the way forward by addressing new challenges and mutually tuning each other to each industry's requirements. It is anticipated that, as a result of the above reports, there will be a rebalance of powers with the banks benefiting most. Although partnerships are formed between banks and insurers, and reforms in the distribution of life products are expected, it is still difficult to forecast growth in bancassurance. Moreover, historical and regulatory differences among financial intermediaries have to be revisited to better reflect the needs and preferences of modern financial markets, while public policy issues need to be considered as well. ${ }^{15}$ So far, the study has briefly reviewed the European trends in the banking and insurance industry. The phenomenon has become the subject of analysis in a number of research studies and this is what the next section explores.

\section{A brief look at the literature}

The work on financial conglomerates could be placed under the wider umbrella of mergers, acquisitions and corporate restructuring. ${ }^{16}$ The latter covers a wide spectrum of studies ranging from theories of regulatory restrictions and innovations to quantitative methods measuring the viability of such synthetic business entities. Thus, to keep the task manageable, this section aims to briefly overview the literature with no intension to lessen the importance of any studies excluded. ${ }^{17} \mathrm{~A}$ large volume of research has concentrated on analysing and identifying the kinds of synergies that might exist between traditional banking and insurance activities. The methodologies employed usually aim to examine market data (stock prices, spreads, etc.), accountingbased measures and/or changes in the risk-return profile of the corporations involved.

The examination of stock market prices was always central in the broad finance literature, with event studies being one of the tools in the area of financial conglomerates. Following the Citicorp-Travelers Group merger, Carow $^{18}$ reveals

system with a 'defined payment agreement' scheme. One of the triggering factors was the U.K.'s $£ 27$ billion savings gap between what people are saving and what they need to afford a decent retirement. In July 2002, HM Treasury published a report by Mr. Ron Sandler, former chief executive at Lloyd's of London, on the retail savings market. The aim was to counteract what he saw as a market failure. In particular, his concern centred on the availability of a wide range of complex products, which required relatively costly regulatory requirements over the sales process. This, he believed, acted as a barrier to the purchase of products by consumers who could benefit from straightforward, lower risk products. Finally, at the same time Allan Pickering, former chairman of the National Association of Pension Funds (NAPF) and partner at Watson Wyatt, one of the "big four" actuarial firms, makes 52 recommendations for the pension's industry. Among the key ones are (a) a new pensions act to consolidate all existing private pensions legislation, (b) a new more proactive regulator, (c) a better, more targeted approach for communicating with pension scheme members, (d) more flexibility to modify schemes, (e) allowing employers to make membership of their occupational pension scheme a condition of employment and (f) the ending of compulsory indexation for defined benefit pensions and compulsory survivors benefits.

15 Santomero (1989); Herring and Santomero (1990); Van den Berghe and Verweire (2001).

16 Sudarsanam (1995).

17 An extended reference list is available from the author upon request.

18 Carow (2001a). 
significant stock price increases for large banks and life insurers, while insignificant changes are reported for non-life insurance firms, as a result of deregulation. Similar positive size-related effects are reported by Johnston and Madura. ${ }^{19}$ They interpret the positive stock price movements to be predicting that regulators would be forced to allow future combinations of financial companies, while the size effect is due to greater efficiencies to be realized by larger distribution networks. Carow $^{20}$ hints a word of warning, as insurance values are plummeting as a result of court rulings to allow banks to sell annuities and insurance products. ${ }^{21}$ The bank stock price, however, does not change around the court-ruling events. In a similar framework, Carow and Heron ${ }^{22}$ find positive returns for investment banks and insurance firms; negative returns for foreign banks, thrifts and finance firms; and insignificant returns for commercial banks. Looking at the securities market, Gande et al. ${ }^{23}$ find that while Section 20 deregulation appears to have resulted in a significant decline in underwriting spreads in the corporate bond market, similar declines are not apparent in equity markets, where banks have not yet made significant inroads.

Complementing the above findings, a number of studies have focused on figures obtained from financial statements and other economic reports. Using synthetic organizations of banking and insurance agency/underwriting activities, Litan ${ }^{24}$ finds that the returns on various insurance activities are negatively correlated with those of banking, with the latter clearly appearing to be among the least risky activities by exhibiting low variance and low mean returns. Insurance agency operations appear to be the most risky, but the highest yielding activity. Similar conclusions were also reached earlier by Johnson and Meinster. ${ }^{25}$ Boyd and Graham and Boyd et al. ${ }^{26}$ extend their previous work ${ }^{27}$ to investigate the risk-return implications of expanding BHC activities. Profitability of broking and underwriting of non-life insurance business exceeds that of $\mathrm{BHC}$, but all insurance activities are more risky according to their measures. Using a simulation methodology, it is found that bankruptcy risk falls slightly when banks merge with life assurance, but the same risk rises when banks merge with P\&C or insurance broking or securities or real-estate firms. It is also found that the return on equity would have been slightly higher had agency activities been allowed, but slightly lower had P\&C and life underwriting been permitted. In a European framework, Brown et al. ${ }^{28}$ conduct a simulation study of banks and building societies diversification into life assurance. It is found that building societies and mutual life insurers would be significantly risk reducing. Recent empirical

\footnotetext{
19 Johnston and Madura (2000).

${ }^{20}$ Carow (2001b).

${ }^{21}$ In essence, Carow (2001b) examines the theory of contestable markets, where structures other than perfect competition may be optimal.

22 Carow and Heron (2002).

23 Gande et al. (1999).

${ }^{24}$ Litan (1987).

25 Johnson and Meinster (1974).

${ }^{26}$ Boyd and Graham (1988); Boyd et al. (1993).

${ }^{27}$ Boyd and Graham (1986).

${ }^{28}$ Brown et al. (1996).
} 
evidence by Lown et al. ${ }^{29}$ points most strongly to combinations of banks and life insurance firms. They report stock price increases for both sectors surrounding the launch of the 1999 Gramm-Leach-Bliley Act. Elsewhere, the issue of economies of scale/scope has been examined by Jung et al. ${ }^{30}$ where they showed that banks are more revenue efficient, while insurers are more cost efficient.

Others have delved into accounting and market data in their effort to examine the bancassurance phenomenon. Cost and profit efficiencies are adeptly analysed by Vander Vennet. ${ }^{31} \mathrm{He}$ finds that trends towards further de-specialization could lead to a more efficient banking system. He also shows that universal banks are more dominant in terms of operational and profit efficiency when compared to their specialized competitors. More recently, Fields et $a l .{ }^{32}$ competently examine the specialness of interface between banks and insurance firms. The results suggest that bancassurance mergers are positive wealth-creating events, while total or systematic risk is unaffected. Economies of scope and diversification are identified as the main sources of bank-insurance synergies.

Within a risk-return framework, Nurullah and Staikouras ${ }^{33}$ find an increase in profitability and no risk change for hybrid structures between banks and insurance broking firms. Other studies provided evidence that the probability of failure is greater for non-banking subsidiaries than for banking subsidiaries or that diversification gains were relatively small. ${ }^{34}$ Empirical findings also show that risk is greater in non-banking than banking, while mergers of bank holding companies with life assurance or $\mathrm{P} \& \mathrm{C}$ firms reduce risk, whereas the latter increases with insurance broking. ${ }^{35}$ Elsewhere, Saunders and Walter ${ }^{36}$ find that expanding banking activities reduces risk, with the latter stemming from insurance rather than securities activities. They also argue that the convergence would enhance the static and dynamic efficiency of financial institutions, without increasing the risks to financial stability. Using U.K. data, Genetay and Molyneux ${ }^{37}$ simulate mergers among banks/ building societies and mutual and proprietary life insurance companies. Mixed evidence on risk is obtained with significantly lower probabilities of failure but insignificant changes in return on assets' volatility for bank/insurance company combinations.

Unlike the aforementioned stream of research, reviews and qualitative analyses are also available. Looking at the previous research, Carow and $\mathrm{Kane}^{38}$ conclude that the abolition of regulatory barriers may have redistributed rather than created value. Further analysis has also been conducted regarding the current and future

\footnotetext{
${ }^{29}$ Lown et al. (2000).

30 Jung et al. (2003).

${ }^{31}$ Vander Vennet (2002).

${ }^{32}$ Fields et al. (2005).

${ }^{33}$ Nurullah and Staikouras (2004).

${ }^{34}$ Wall (1987); Kwast (1989); Rosen et al. (1989).

${ }^{35}$ Liang and Savage (1990); Boyd et al. (1993).

36 Saunders and Walter (1994).

${ }^{37}$ Genetay and Molyneux (1998).

${ }^{38}$ Carow and Kane (2002).
} 
exclusionary regulations. ${ }^{39}$ Drawing from the Greek experience, Staikouras and Staikouras and Kalotychou ${ }^{40}$ examine the evolution of the bank-insurance model, in a cross-section and time-series framework, as well as the growth of the market-based ventures in the region. Kazantzis ${ }^{41}$ provides a thorough critical review of the Greek financial sector, discusses the possible interface among financial services and points out the need for product differentiation and target diversification. One of the early studies on bank holding companies regulation, ${ }^{42}$ however, raises the issue of risk proliferation, as well as the social cost of dealing with it, while Saunders ${ }^{43}$ elaborates the arguments for universal banks and argues that the phenomenon would improve the competence of financial institutions. Morgan et al. ${ }^{44}$ provide an insight into the French and U.K. experience by analysing its implementation, the roots of differences between the two countries and the process of innovations from a strategic perspective. Molyneux et al. ${ }^{45}$ and Genetay and Molyneux ${ }^{46}$ provide an excellent overview of bancassurance in Europe and document its historical roots dating back to the 19th century. Finally, Van den Berghe and Verweire ${ }^{47}$ distinguish between the financial and institutional aspects of bancassurance and report that the risk profile of financial conglomerates is better when compared to vertically divided markets.

\section{Blending diverse cultures and networks}

Referring to the institutionalization of bancassurance and its variants, one basically means the harmonic co-existence of credit and insurance providers under the same roof. These are two sources of vital financial services, which are simultaneously competitors as well as essential complements to each other. The latter stems from the fact that the two institutions aim to satisfy distinctive but inter-related needs of their customer base - in the broad sense of savings, investments and insurance provisions while the former refers to the de jure limits and/or de facto boundaries - as expanded by loopholes and avoidance activities ${ }^{48}$ - between the two. ${ }^{49}$ The two markets have

${ }^{39}$ Kane (1988, 1996a, b).

${ }^{40}$ Staikouras (2005); Staikouras and Kalotychou (2005).

${ }^{41}$ Kazantzis (2000).

42 Black et al. (1978).

43 Saunders (1994).

${ }^{44}$ Morgan et al. (1994).

${ }^{45}$ Molyneux et al. (1997).

${ }^{46}$ Genetay and Molyneux (1998).

47 Van den Berghe and Verweire (2001).

${ }^{48}$ In fact, the process can be viewed as a "game" where the sequence becomes one of financial innovation, re-regulation and avoidance, which in turn results in an endless cycle where regulation and avoidance embrace each other in a series of lagged reactions. A pertinent vivid example is the Citicorp merger with the Travelers insurance firm. Despite the fact that the creation of Citigroup is the symptom of hunting superior profits through financial innovation, it is still one of the triggering factors behind the realignment between state laws and economic realities.

${ }^{49}$ Kane (1988, 1996a, b); Staikouras (2005); Staikouras and Dickinson (2005); Staikouras and Kalotychou (2005). 
worked in parallel without any problems for many decades. Co-operation has been easily detected with the demarcating boundaries being clear-cut as well.

Over the last two decades, however, the two industries began an interface with their representatives, bankers on the one side and insurers on the other, realizing the potential mutual benefits of such convergence. Bancassurance advocates argue that synthetic financial structures enhance managerial discipline, allow economies of scale/scope, promote financial stability and economic development as well as being a form of more efficient restructuring. On the other hand, the trend raises concerns, with the sceptics further scrutinizing it. Challengers of financial conglomerates claim that obstacles such as conflict of interest, non-real cost reduction gains and monopolistic power make the trend unfeasible and precarious. The debate still remains an open issue with clearly established arguments, ${ }^{50}$ while Santomero and Eckles ${ }^{51}$ stress the importance of examining the roots of such trend, its operational characteristics, the strategic benefits of those partnerships as well as the role of governing bodies and regulators.

Banks and insurers lean on the bancassurance channel for different reasons. It is evident that credit institutions are moving to protect themselves against the evertightening squeeze in margins in their traditional retail banking. The engineering of the new corporate structure is seen as a growth opportunity by banks, as well as a steady stream of commission income. Banks are seeking to exploit their loyal customer base to grab a larger share of household wealth. From the insurers' point of view, bancassurance offers the prospect of reduced distribution costs compared to the traditional agent channel. Insurers are also strategically aiming to seize the opportunity of reaching new customers not easily accessed by their agent network. Banks are bigger, financially stronger and with greater name awareness than insurers, from which the latter could benefit. Yet, one of the obstacles to overcome is the difference between the commercial banking and insurance culture, particularly with reference to life insurance.

Both sectors have a distinctively different philosophy and behaviour both at corporate (aggressiveness, employee turnover, remuneration) and retail level (in terms of informing, servicing and acting on behalf of their customers). Banks have had difficulty marrying the sales culture of insurance with the softer culture of the bank branch. The synergy of working together has rarely been achieved, although the potential is momentous. Insurance is associated with marketing innovation, consultative selling and incentive compensation. On the other hand, commercial banking culture is one of relationship building, little risk, stability and compensation schemes less related to performance. ${ }^{52}$ In general, the insurer is a salesman, constantly on the move, whereas the banker works in a branch. The insurer seeks out the prospective customer, talks to him personally, is trained to talk and explain risk and assumes risk on behalf of the company. The banker waits for the customer at a sale's point, addresses issues to a group of customers, while he is trained to secure risk on behalf of the bank.

\footnotetext{
${ }^{50}$ Saunders (1994).

${ }^{51}$ Santomero and Eckles (2000).

${ }^{52}$ Risk is greater in investment banking, which is inter-linked with entrepreneurship risk-taking and incentive compensation.
} 
As previously discussed, many insurers have already teamed up with banks, since partnerships with the latter are seen as essential for distribution purposes and economies of scale/scope. In view of the cross-country experience, however, the signals are mixed for whether bancassurance is the distribution channel that will prevail in the future. Market practices across Europe are very different and one should not be surprised if some of the channels will under/outperform any forecasts. The way various products are promoted and distributed is crucial to the successful design of the bancassurance structure. Bankers and insurers should carefully integrate, in their business structure, the various aspects that determine the competent promotion of their products/services. Competent not in terms of increasing their sales, but in terms of identifying real customer needs and effectively satisfying them.

\section{Bancassurance multi-layer platforms}

Essentially, the complexity of the issue boils down to a triangular approach accounting for product complexity, distribution infrastructure and market integration and/or globalization. The latter is one of the most important determinants of how people perceive risk and accordingly react in modern financial markets. The term "market globalization" refers to the level of market integration with developed economies and how segmented the industries are, in the sense of sharing activities and/or collaborating. ${ }^{53}$ In addition to that, market globalization engulfs areas of openness indicating how receptive the market is to new ideas, external influences, nontraditional practices, cultural issues, etc. It is expected that the more open the economy is, the more influences will take place and the more experimentation will be observed. Experimentation is usually the result of product/service engineering in modern financial markets. The more global (domestic) the market and more complex (simple) the products, the more (less) mandatory the presence of knowledgeable and specialized contacts. This in turn implies the existence of a multi-layer service within the universal intermediary.

Figure 2 represents a proposition for a radar-shape design of the distribution platform. It is a proposition to better understand the bank-insurance phenomenon and make it viable and beneficial for both financial markets and individuals. The proposed radar-shape approach enfolds all necessary promotion layers that comprise the distribution platform.

Figure 2 envelops four different isosceles triangles mirroring a complete multi-layer approach. The three axes starting from their intersection in the centre of the triangle represent dynamics, which in turn affect the promotion and service platform(s) employed or necessary to be adopted by the corporation. As one moves away from the centre of the triangle, the magnitude of the three dynamics changes, postulating the need for a multi-layer and/or more sophisticated service. The labels at the end of the axes denote the level of those dynamics at this particular point, which is exactly the opposite of the one observed at the axes' intersection.

\footnotetext{
${ }^{53}$ A segmented/fragmented market has exactly the opposite characteristics.
} 


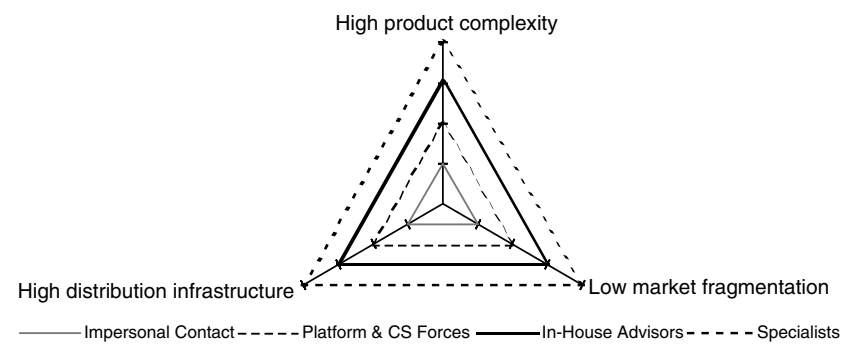

Figure 2. The radar-shape approach to a multi-layer platform.

The smallest triangle, close to the intersection of axes, represents the rudimentary layer of product promotion and potential sale. We refer to this tranch (or tier) as the impersonal contact, which is usually observed when the market is highly fragmented, the distribution infrastructure is minimal and the products available are very basic. This usually takes the form of customers visiting the Internet, obtaining information through advertisements, television and responding back by mail or telephone. These are simple packaged products, easily identified without requiring the presence of a financial/insurance representative. In most European countries, telephone and Internet deals have become the norm.

The second triangle, drawn with the segmented line, represents three facets of the market, which are more advanced than the ones observed in the previous tier. We refer to this tranch as the platform and commissioned sales forces, which is usually observed when the market is at a higher level of integration, distribution resources and product complexity than the previous one. Platform forces are usually bank employees that can spend limited time with their customers, due to their other duties, and usually refer the client to the financial advisor or the insurance representative. Their role within the bank can vary, as they could be information providers, customer service advisors, loan assistants, etc., and can usually sell simple products. Commissioned sales agents usually represent independent contractors and could be an effective sales force as long as they are closely monitored, so that sales quantity does not become the substitute for sales quality. It is easy to design a high commission product and suffer the loss of being unable to identify the relevant clientele. In the bancassurance framework, the base should consist of the targeted market share and the needs of the customers (that is, both the financial institution and the agent guide) and serve the client according to their preferences.

The third phase, with the hazy solid line, signifies a market with a relatively high degree of openness, significantly increased distribution services and the launch of multipart products. Thus, the need for in-house advisors is apparent. These should usually be employees tied to the insurance branch with good knowledge of the insurance products available and able to further identify customers' needs. For example, a withdrawal from a deposit account could be associated with the purchase of a car, holiday package, domestic appliances, property or even relocation. An insurance advisor clearly knows that all the above cases require some sort of insurance such as personal accident, travel, content, etc., and should be able to advise the client and promote the pertinent product. The aforementioned cases are only limited 
examples, as the insurance employee should be able to promote a wide range of other services ranging from death, career change, birth, divorce to natural catastrophes, terrorism attacks and many more.

The highest level of interaction is observed when the market is fully integrated, distribution networks are sufficient and financial engineering constantly enhances product complexity. This tranch is the outer isosceles triangle connecting the edges of the three market dynamics. At this stage, it is important that the corporate venture seek the advice and services of bancassurance specialists for further generating leads and increasing sales. The specialists are employees that have excellent knowledge of both banking and insurance products and can offer advice and guidance in the combination of the two. At the same time, all the above-mentioned network resources should be offered in parallel, depending on the market preferences and the potential clientele.

The discussion so far has facilitated the presentation and analysis of the interaction between distribution platforms and market dynamics. The proposed triangular illustration segregates the network's distribution blocks into four broad different pieces, but in practice it becomes more complicated, as market dynamics and network platforms are indistinctively inter-related. For expositional simplicity, one may graphically observe the aforementioned isosceles triangles; in reality, however, platforms with three different (non-equal) dimensions are frequently observed. This is part of the market's evolution process and it will only be a matter of time until market forces eventually push all dimensions at the same level. Figure 3 presents such a disequilibrium state or transition period.

In Figure 3, the market is open to influences (low market fragmentation) and has a number of complex financial products, but the distribution resources are not enough or adequate to facilitate the needs generated by product complexity and market openness. Dimension misalignment will only take place as a transitory period until market "equilibrium" is restored. That is, one "cannot" observe, for a long period, complex products and adequate distribution infrastructure with the market being segmented or less integrated/global. Similarly, one "cannot" experience in a very integrated (least segmented) market the absence of complex products and non-existent distribution building blocks. It is, therefore, evident that any combination among the three forcing variables is possible during a transition phase. Between any transition point and the subsequent equilibrium level there would be a time lag, which will mainly mirror the battle among various market dynamics (supply, demand, regulation, competition, entrepreneurship, etc.) until an isosceles triangle (equilibrium) is formed.

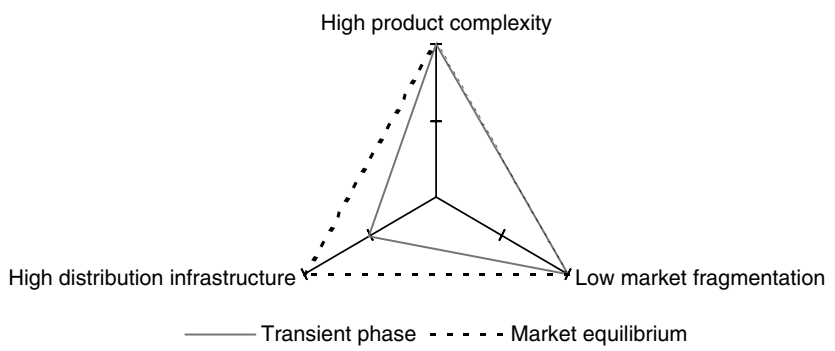

Figure 3. Transition phase vs. market "equilibrium". 
As we move away from the intersection of axes, we clearly observe the various challenging levels of product promotion and advice required. The most effective way for the corporate venture to achieve its goals, strategic and financial, will be driven by the clientele needs and market preferences rather than products.

\section{Mode of entry and risk-success drivers}

The seismic shockwaves sent across Europe by the Allianz acquisition of Dresdner Bank, in 2001, signal that combined banking and insurance superpowers might be the type of corporate structure to dominate European financial services in the future. A transatlantic strategic move that caught the eye of the practitioners and academics alike is the Citicorp-Travelers Group merger in October 1998. With that move, Citigroup not only affected its own future, but the future of peer institutions, as well as the Federal policy per se. Yet, strategic comparisons with the Citigroup model may be flawed, as the track record of such combinations is decidedly mixed. ${ }^{54}$ The profile of the bancassurance specification, however, will differ among countries and institutions alike. Its exact structure is subject to influences by a number of exogenous and endogenous factors. The former refers to economic, regulatory, tax-related, legislative and demographic features of the environment where the bank and insurer operate. The latter are mainly factors related to the strategy of the firm, its management and philosophy, the characteristics of its clientele, the particular product provisions and possibilities/plans for expansion. In general, the demographic profile of a country decides the kind of products bancassurance will be dealing with, the economic situation will determine the trend in terms of turnover, market share, etc., whereas the legislative, as well as the tax and regulatory climate will demarcate the periphery within which the bancassurance operates. The endogenous factors are more likely to influence the decision of the insurer to enter into this particular business arena, and in most cases are more resilient to changes than the exogenous elements.

\section{Modelling financial institutions interface}

Across various markets different players have adopted different variations of the bancassurance model in terms of life and pension providers. Thus far, the analysis has focused on the way the market functions and has suggested a multi-layer distribution network based on three fundamental drivers. The adopted corporate strategy is usually determined by the partnership arrangements established between bankers and insurers. It is worth mentioning, however, that the current consumer trends, legislation and the existing networks and services have also a role to play in determining the bancassurance structure. Thus, this section aims to categorize the corporate ventures in accordance with market practices (usually known as "the mode of entry") employed across Europe. The phenomenon poses a real governance challenge, especially when considering that strategic alliances are frequently subject to high instability, poor

\footnotetext{
${ }^{54}$ At Citigroup, for instance, the much talked about cross-selling synergies have taken place on the corporate banking side rather than on the retail banking section.
} 
performance and longevity. ${ }^{55}$ Dyer and Singh $^{56}$ show that competitive advantage is vital to the survival of any alliance, while through a relational view they identify knowledge, relation-specific assets, effective governance and resources as the key fundamentals for success.

The first approach is the horizontal alliance, where the bank enters into an agreement with an insurer(s), with the insurance products being promoted through the bank's branches (over the counter) or the bank directs its customers to the particular insurer(s). This strategy is also known as the multi-tie approach, while the process of directing bank clients to a specific insurance firm is known as referral. The bank can choose more than one alliance depending on the variety and quality of products provided by each insurance provider. Note that the reverse is always an option, where the insurer takes the lead, while several banks (usually small to medium size) provide access to middle-market leads. One appealing feature of such strategic cooperation is that there are no restrictions involved and both parties remain autonomous. Nevertheless, the balance of powers is a matter under negotiation, and then an interesting question surfaces: who is now responsible for any integration costs and efforts involved?

The second approach is the vertical venture, where in that case the insurer is a subsidiary of the bank and is controlled by the latter. The banking corporation is held responsible for implementing and controlling the integration process. In that venture, common strategies are set and the strengths of both partners can be exploited. The bank sells branded subsidiary insurance products, while the insurer sells its own branded products as well. Some of the services can also be specifically designed for the banking customers or others redesigned to meet the needs of a potential new clientele. As in the previous case, the reverse structure is equally viable, where the bank is a subsidiary of a big insurer.

The third structure is the integrated partnership, where the bank and the insurance firm belong to the same group and both use their networks to sell their products. Under this structure, partnership loyalty is present and common targets are set, while full control of the cross- and up-selling process is feasible. This structure also forestalls inter-sector antagonism and/or potential rivalry. In a number of cases, both banks and insurers can also establish an "autonomous" arm specializing in bancassurance products, which is governed by both parties. The latter calls for a joint venture of a large bank, with a well-developed customer database, together with a large insurer with strong product and channel experience to develop a powerful network. In the current discussion, although the joint venture could be seen as a fourth independent mode of entry, it is assumed to be a subset of the integrated partnership. This is simply a result of assuming that a joint venture could emerge only if both parties dedicate a significant amount of resources, in terms of financial and human capital. Thus, the integrated partnership is probably the most likely structure to sustain such resources and grant access to them. Nonetheless, assuming that it still remains a subset of the above modes of entry, then any conglomerate (vertical venture) could also be able to

\footnotetext{
${ }^{55}$ Parkhe (1993a, b).

${ }^{56}$ Dyer and Singh (1998).
} 


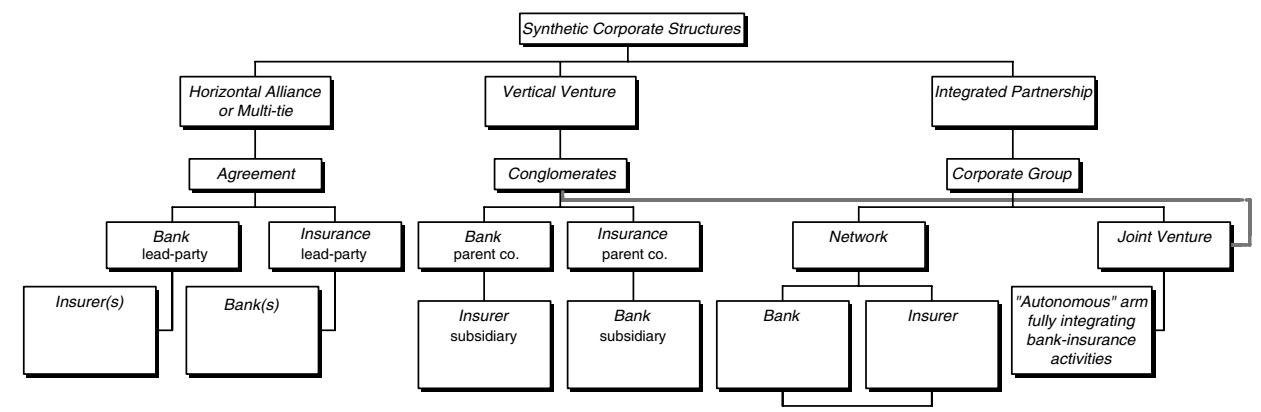

Figure 4. Market-based bancassurance models.

set up an "autonomous" joint venture. The latter is depicted in Figure 4 using an auxiliary segmented line. If none of the above structures are desirable, bankers and insurers could still rely on a third party, such as a broker, to integrate their divergent skills. This is not considered, however, as an extra or even innovative model, since it simply boils down to the agency/broker approach already employed by insurers. The following illustration presents the most commonly employed partnership arrangements, as explained before.

These models are by no means exhaustive, but still remain as the three broad categories, as other structures could emerge depending on the market, economic, legislative environment as well as cultural factors. Moreover, banks and insurers may simply maintain distribution channels with each other without forming a separate firm, thus requiring less capital investment than with a complete acquisition. ${ }^{57}$ Strategic alliances are usually seen as a fertile territory for industry product expansion and for exploiting a market niche via superior competitiveness. ${ }^{58}$ On the other hand, unless there is a truly committed partnership, these alliances usually suffer from instability, premature dissolution and underperformance. ${ }^{59}$ In modern financial markets where mergers and acquisitions have become the norm, ${ }^{60}$ it is also practicable that the multinational conglomerates may concurrently experience all three forms, in one way or another, in their operations across the world. When corporations start expanding and gaining international status, thorough examinations of each potential partnership becomes crucial. Both careful planning and analysis remain the cornerstone of the bank's strategy in order to understand the political and social culture of the targeted region, as well as the regulatory environment, while meticulously training and monitoring its agents, including their approach and selling

${ }^{57}$ Gardner et al. (2000).

${ }^{58}$ Dyer and Singh (1998).

${ }^{59}$ Parkhe (1993b).

${ }^{60}$ The ING Group came as a result of the 1991 merger between Nationale Nederlanden and NMB Postbank Group; Credit Suisse as a result of the merger with Winterthur (1997) and with First Boston (1988) and acquisition of Donaldson, Lufkin and Jenrette (2000); and the Swiss insurer Zurich Group merged with the financial services business of BAT industries in 1998. For an excellent discussion on the issues surrounding mergers and acquisitions, see Sudarsanam (1995). 
points to their clients. ${ }^{61}$ The suggested framework may well seem operational in a theoretical context; it would be interesting, however, to further identify the possible risk-success corporate factors underlying the formation of the new hybrid financial entity.

\section{The underlying risk-success corporate dynamics}

So far, the discussion and analysis have concentrated on the features that influence the provision of financial services and the modelling of the universal financial intermediary. But are these elements enough to navigate managers and entrepreneurs through the Scylla of beguiling corporate risks and the Charybdis of mesmeric structural innovations? On the basis our earlier discussion, there is not a precise enterprise structure that stands out as being significantly more rewarding than others. It is, therefore, sensible to identify and contemplate the possible corporate drivers that distinguish one business venture from another in terms of being successful and viable. More specifically, the current study proposes three key corporate factors for the bancassurance success/risk, namely market based, strategic and operational. The former deals with the market in its broad context, such as industry issues not entirely controlled by the firm, while the strategic and operational components refer to the particular synthetic enterprise structure, which usually involves elements that a certain business could influence, amend and/or change. In essence, the paper suggests that the aforesaid elements can be broadly grouped into exogenous (market-based) and idiosyncratic (strategic and operational) dynamics. The dual capacity (success/risk) of those drivers stems from the fact that if properly exploited and/or accounted for, then they become elements of success, while if they are overlooked, they simply backfire and become hazardous.

The first market-based factor under consideration is the economic growth of the particular target zone. The relationship between the growth of GDP per capita and size of insurance markets is well established. Emerging markets with continuously improving economic fundamentals are probably ideal candidates for bancassurance ventures. Developed economies provide a fertile territory as well, since financial engineering constantly creates products that are appealing to the wide market base. The demographic features of the target region silently contribute to the formation of any financial phenomenon. Changes to the age (due to fertility/mortality) of regional clientele, redistribution of population (due to migration), behavioural and psychological characteristics, as well as religion, ethnic background, education level and profession can have a profound effect on the viability of the various product/services provided. $^{62}$ On the other hand, a favourable regulatory and tax environment is probably the most important market driver after all. A vivid example is the correlation between the tax advantages offered in some countries and the development of

${ }^{61}$ Corman (1998).

${ }^{62}$ An interesting example that clearly illustrates how financial services can be affected by demographic characteristics is when the price of crude oil fell dramatically in 1986. At that time, many Islamic borrowers with significant indebtness to U.S. banks invoked the Doctrine of Sharia, which holds that the payment of interest is against the teachings of Koran. 
bancassurance links. Combining customer databases can also help identify insurance opportunities, but many regulators restrict the activity. Despite any restrictions imposed by regulators, access to multiple databases remains a vital component of the closely integrated bancassurance model.

The second class of success/risk factors is related to strategic elements adopted by the financial conglomerate. The business culture is a crucial and quite diverse area, encapsulating many aspects of the corporate spectrum. The two businesses have distinctively different attitudes, as discussed in the previous section. Inflexibility towards accepting and adopting each other's culture does not lead anywhere. The new hybrid structure should vigorously educate and train all its employees towards a culture that will maximize the corporate value. The new attitude is neither about banks nor insurance, but bancassurance venture and the associated products. Thus, it has to be adaptable to the needs of the custumer base and the nature of each particular product. Likewise, effective communication during the launch process, as well as at later stages is important for investors, employees and customers. The corporate closeness between the bank and the insurer is material to the success. That is, deeper integration between the two businesses should normally lead to more interdependence, corporate loyalty and joint efforts in achieving common targets. On the whole, the question that emanates is: how could both parties make themselves indispensable to ensure they benefit from the new business venture? We think that the most sensible and overarching response would be: their ability and willingness to integrate. Thus, deeper integration is the strategic move, provided the regulator allows it. Nevertheless, this aspect has attracted a lot of attention and is quite controversial, as others argue that entities do not necessarily need to merge to reap benefits maximally. ${ }^{63}$ The key to making conglomerates work is about how they realize the synergies they have in mind. In fact, organizational structure does not always matter. It is all about the management activities you put in place to realize the right synergies, which directly links with the "management initiative" driver discussed below. More research is necessary to investigate this, but researchers like Haspeslagh and Jemison ${ }^{64}$ and Goold and Campbell ${ }^{65}$ have done some very interesting work in this respect. Over the last decade, corporate governance emerged as a major strategic factor. Financial markets became painfully aware of its importance through corporate management disasters. Potential bancassurance ventures should ensure that each partner has proper governance procedures in place, which are always met and reviewed on a regular basis. Last but not the least, management initiative is probably the most decisive strategic factor to success. It is certainly difficult to gel the two diverse cultures of banking and insurance, so both management teams have to make an effort. Top management must drive the project and adopt the right attitude to understand and be receptive to changes - the strategy must be imposed from the top.

Operational factors, on the other hand, include idiosyncratic characteristics such as a suitable branch environment in order to generate leads and increase sales. A carefully

\footnotetext{
${ }^{63} \mathrm{I}$ am grateful to the referee for triggering this discussion and providing this perspective.

${ }^{64}$ Haspeslagh and Jemison (1991).

${ }^{65}$ Goold and Campbell (1998, 2002).
} 
considered bank-insurance venture should enfold sales personnel under the same roof aiming at the targeted financial and/or operational synergies. Customer relationships are essential, as it would be easier for the bank to sell a new product to its existing clientele. The existence of a single sales point to disseminate information about multiple products and services, and hopefully generate sales, would certainly reduce the risk of customers turning to other institutions. Thus, contact points are primarily an advantage that banks have with their numerous local branches. Furthermore, the range of services offered is central, as it will certainly shift the public's perception of the bank's role. Both bankers and insurers should pursue relationships with institutions that can or have the potential to offer a wide range of products. The latter will attract new customers from other institutions, increase sales and hopefully produce the desired synergies. Limited range of services could result in expensive marriages without necessarily generating the desired market share. As far as financial management is concerned, careful weighting of the distribution costs should unveil that the new structure is cheaper than the classic agent channel. Proper financial analysis would unearth grey areas and simultaneously highlight possible benefits through economies of scale/scope, assuming that the two sectors are willing to integrate their divergent skills. Finally, corporate brand values related to trust are equally important, as insurance is rather a longer-term commitment than ordinary banking business. To a large extent, consumers have not yet developed the "trust relationship" with the insurance industry. They are always cautious when it comes to insurance and sales of related products, but paradoxically they seem to value more their relationship with the bank. A diagram of the main issues covered in this section is provided in Appendix A.

Apart from the factors described above, there is a set of dynamics that could have both an exogenous and idiosyncratic status. More specifically, these drivers are technology and reputation. Technology could be a market factor in the sense that the firm or proposed venture has no influence on it, while at the same time be an operational/strategic feature simply because the corporation decides to adopt it or dispose of it. Technology is probably the newcomer in determining an effective and efficient cooperation. The winners and losers will be separated by their ability to leverage emerging technology to reinvent their business. The growth in e-business and technology applications over the last few years has created a number of opportunities to redefine how insurance products are manufactured and distributed. Manufacturing refers to product development, underwriting, and product portfolio management, while distribution includes activities related to customer service and originating new business. An interesting example is the Spanish bancassurer BBVA Seguros, which has increased the number of branches but decreased the number of employees. By investing heavily in IT, they now operate with an average of six employees per branch in comparison with 11 in the U.K. On the other hand, corporate reputation ${ }^{66}$ was until recently a forcing variable quietly ignored. Unlike other factors, one should bear in mind the intangible nature of reputation. Reputation has intrinsic value mainly

\footnotetext{
${ }^{66}$ Reputation is defined as the overall perception, residing in market's participants mind, regarding an organization. It is generally formed as a result of current/past experiences and expectations.
} 
stemming from the company's management, regulatory compliance, employees' satisfaction, governance, social responsibility, performance, ethics, innovation, etc., hence its operational status. At the same time, reputation shapes market's behaviour to influence future value, hence its exogenous (market-based) side. That is, reputation is formed as part of a company's overall behaviour, but it is then adopted by the market and subsequently influences investors, consumers, suppliers, costs, expectations, media, etc., and remains outside the firm's control for a period of time. The latter simply mirrors cases where shifting the market's perception regarding corporate reputation is always time consuming and financially expensive. Thus, reputable bankers and insurers should look at each other and identify business opportunities either locally or abroad depending on the current regulation in force. One of the most influential aspects of reputation is probably its ability to provide the benefit of the doubt when a crisis occurs.

\section{Concluding remarks}

The effects of financial innovation on the economic system, on the structure and operation of financial intermediaries and ultimately on the ordinary taxpayer have made their presence felt over the last decades. In the U.K., following the Sandler recommendation for simplified products and with the CP121 paving the way for multitie advisors and product-orientated (rather than sales) regulation, the future of the financial services industry is under the plough. To this end, the current work discusses and analyses various aspects of the decompartmentalization of the banking and insurance industry.

Looking at the financial services landscape, there is ample evidence of the fertile terrain on which the integration of sectors is thriving. The majority of the developed countries within the European area are experiencing a plethora of structural innovations. Yet, there are still developed or developing countries that are making slow progress as a result of regulatory, tax-related and/or cultural obstacles. Both academics and practitioners have put the phenomenon under the microscope using quantitative techniques, descriptive examination and/or strategic and management-orientated approaches. The quantitative findings today seem to be too diverse to justify an enhanced risk-return profile for the newly born hybrid intermediary. Others have expressed thoughts of ostensible financial benefits to taxpayers due to exclusionary regulation, while some researchers have looked at corporate synergies, regulatory standards and cross-market responses. On the basis of market practices and previous academic work, this paper points out issues related to the diverse cultural attitude of the two industries and proposes a radar-shape approach for a multi-layer promotion/service network. Issues related to structural and/or market disequilibrium are also identified and discussed. The modelling of the integration process is conceived under three broad structural innovations being identified in the European market. Finally, various risk-success elements for these integrated financial structures are analysed both from a market, strategic and operational perspective. 
The discussion and analysis in the present study have hopefully identified areas where financial institutions, governing agencies and regulatory authorities have to concentrate on in order to make their economic systems forward looking. In what follows, the paper raises a few questions aiming to stimulate further research and conceive the future of universal financial institutions and/or insurance. From the point of view of portfolio diversification, it seems sensible to allow banking organizations to engage in non-banking activities. As many of us could argue, broadening banking firms' revenue base can improve their earnings stability and provide them with a better trade-off between risk and return. But the empirical studies fail to provide a solid endorsement of such hypothesis. On the other hand, looking at the U.K. market there is tangible evidence that the life and pensions' industry is failing both its customers and society as a whole. Possible trends over privatization of state pension funds may well impel these institutions to further engineer new financial products. The U.S. has twice the size of the European asset management market with the latter being firmly expanding. Thus, a new route might be paved for both bankers and insurers, where fund management could be an integral part of the bancassurance operation.

Furthermore, should one expect the banking industry to manufacture and underwrite products or would it be more sensible to recognize its limitations and become a powerful distributor? The point worth exploring here is not so much the ability of the bank to perform such operation, but rather its implications for the market and the economy as a whole. The integrated financial services provision could be beneficial for the economy, sector and the intermediary itself by enhancing the quality of financial services, reducing intermediation costs and reshaping their riskreturn profile. The above benefits are evidently visible in a macro-level, but does the household always benefit from these changes? Clearly, such major restructuring with any subsequent integration is expected to engulf carefully disguized risks. For instance, who is going to pay for integration expenses, restructuring costs, divestments? How is the bancassurance premium going to change in the future? All these may possibly increase opportunities for conflicts of interest and risk-taking behaviour by financial institutions at the ultimate cost of taxpayers, through a publicly provided financial safety net. Besides, have governments and legislators carefully thought about the regulatory framework regarding the offspring of that mega-consolidation? Regulators should not be caught off guard by institutions that might be proved too complex to deal with. The paper by no means discourages any interface, but simply points out the necessity of a carefully planned process to avoid breeding financial conglomerates, which are politically too important to close or ignore.

\section{Acknowledgements}

I am grateful to Mark Flannery and Joseph Lampel for the time devoted to reading earlier drafts and providing their views as well as to David Blake, Paul Dawson, Shelagh Heffernan and Elena Kalotychou for helpful comments. I thank John Boyd and Kenneth Carow for providing helpful information. An earlier version of this paper has benefited by discussions with the participants at the 2005 Wolpertinger Conference at Cass Business School, London. Finally, I am indebted to the anonymous referees for their suggestions. Special thanks are due to Dr Sahad Al-Mosawi for excellent research assistance. The usual disclaimer applies. 


\section{References}

Bergendahl, G. (1995) 'The profitability of bancassurance for European banks', International Journal of Bank Marketing 13: 17-28.

Black, F., Miller, M.H. and Posner, R.A. (1978) 'An approach to the regulation of bank holding companies', Journal of Business 51: 379-412.

Boyd, J.H. and Graham, S.L. (1986) 'Risk, regulation, and bank holding company expansion into nonbanking', Federal Reserve Bank of Minneapolis Quarterly Review 10(Spring): 2-17.

Boyd, J.H. and Graham, S.L. (1988) 'The profitability and risk effects of allowing bank holding companies to merge with other financial firms: A simulation study', Federal Reserve Bank of Minneapolis Quarterly Review 12(Spring): 3-20.

Boyd, J.H., Graham, S.L. and Hewitt, R.S. (1993) 'Bank holding company mergers with non-bank financial firms: Effects on the risk of failure', Journal of Banking and Finance 17: 43-63.

Brewer, E. (1989) 'Relationship between bank holding company risk and non-bank activity', Journal of Economics and Business 41: 337-353.

Brown, M., Genetay, N. and Molyneux, P. (1996) Risk Effects of Bank Diversification into Life Assurance: U.K. Evidence, Bangor: Institute of European Finance, University of Wales.

Carow, K.A. (2001a) 'Citicorp - Travelers Group merger: Challenging barriers between banking and insurance', Journal of Banking and Finance 25: 1553-1571.

Carow, K.A. (2001b) 'The wealth effects of allowing bank entry into the insurance industry', Journal of Risk and Insurance 68: 129-150.

Carow, K.A. and Heron, R.A. (2002) 'Capital market reactions to the passage of the Financial Services Modernization Act of 1999', Quarterly Review of Economics and Finance 42: 465-485.

Carow, K.A. and Kane, E.J. (2002) 'Event-study evidence of the value of relaxing longstanding regulatory restraints on banks, 1970-2000', Quarterly Review of Economics and Finance 42: 439-463.

Corman, L. (1998) 'The liability trap', Banking Strategies 74 (July/August): 23-26.

Dickinson, G. (1993) The Changing Interfaces between Insurance Companies and Bank, paper presented at the 20th Meeting of European Risk and Insurance Economists, Rotterdam, The Netherlands.

Dyer, J.H. and Singh, H. (1998) 'The relational view: Cooperative strategy and sources of interorganizational competitive advantage', Academy of Management Review 23: 660-679.

Eisenbeis, R.A. (1995) Banking and Insurance Characteristics, paper presented at the Universal Banking Conference, New York University.

Fields, P., Fraser, D.R. and Kolari, J.W. (2005) What's Different about Bancassurance? Evidence of Wealth Gains to Banks and Insurance Companies, paper presented at the 2005 Financial Management Association, Chicago, IL.

Gande, A., Puri, M. and Saunders, A. (1999) 'Bank entry, competition and the market for corporate securities', Journal of Financial Economics 54: 165-195.

Gardner, M., Mills, D.L. and Cooperman, E.S. (2000) Managing Financial Institutions: An Asset/Liability Approach, 4th edn., New York: Dryden Press.

Genetay, N. and Molyneux, P. (1998) Bancassurance, London: Macmillan.

Goold, M. and Campbell, A. (1998) 'Desperately seeking synergy', Harvard Business Review 76 (Sept.-Oct.): $131-143$.

Goold, M. and Campbell, A. (2002) Designing Effective Organizations: How to Create Structured Networks, London: Wiley \& Sons.

Haspeslagh, P.C. and Jemison, D.B. (1991) Managing Acquisitions: Creating Value through Corporate Renewal, New York: The Free Press.

Herring, R.J. and Santomero, A.M. (1990) 'The corporate structure of financial conglomerates', Journal of Financial Services Research 4 (December): 471-497.

Johnson, R.D. and Meinster, D.R. (1974) 'Bank holding companies: Diversification opportunities in nonbank activities', Eastern Economic Journal 1: 1453-1465.

Johnston, J. and Madura, J. (2000) 'Valuing the potential transformation of banks into financial conglomerates: Evidence from the Citigroup merger', The Financial Review 35: 17-36.

Jung, S., Lee, S.J. and Lee, B.J. (2003) The Effects of Bancassurance on the Efficiency of Korea's Financial Industry, paper presented at the Annual Meeting of the American Risk and Insurance Association, Denver, CO. 
Kane, E.J. (1988) 'Interaction of financial and regulatory innovation', American Economic Review 78: 328-334.

Kane, E.J. (1996a) 'The increasing futility of restricting bank participation in insurance activities', in I. Walter and A. Saunders (eds) Universal Banking: Financial System Design Reconsidered, Chicago: Irwin.

Kane, E.J. (1996b) 'De jure interstate banking: Why only now?' Journal of Money, Credit and Banking 28: $141-151$.

Kazantzis, Ch. (2000) 'Recent and future developments in the Euroland and Greek financial sectors', European Research Studies 3: 145-151.

Kwast, M.L. (1989) 'The impact of underwriting and dealing on bank returns and risks', Journal of Banking and Finance 13: 101-125.

Liang, N. and Savage, D. (1990) New Data on the Performance of Non-Bank Subsidiaries of Bank Holding Companies, Board of Governors of the Federal Reserve System, Staff Economic Studies 159.

Litan, R.E. (1987) What Should Banks Do?, Washington, DC: The Brookings Institution.

Lown, C.S., Osler, C.L., Strahan, P.E. and Sufi, A. (2000) 'The changing landscape of the financial services industry: What lies ahead?', Federal Reserve Bank of New York Economic Policy Review (October): 39-55.

Merton, R.C. (1994) 'Financial systems and economic performance', Journal of Financial Services Research 4: 263-300.

Molyneux, P., Altunbas, Y. and Gardener, E. (1997) Efficiency in European Banking, London: John Wiley \& Sons.

Morgan, G., Sturdy, A., Daniel, J.P. and Knights, D. (1994) 'Bancassurance in Britain and France: Innovating strategies in the financial services', The Geneva Papers on Risk and Insurance 19: 178-195.

Nurullah, M. and Staikouras, S.K. (2004) The Separation of Banking from Insurance: Evidence from Europe, paper presented at the 17th Australasian Finance and Banking Conference, Sydney, Australia.

Parkhe, A. (1993a) 'Partner nationality and the structure-performance relationship in strategic alliances', Organization Science 4: 301-324.

Parkhe, A. (1993b) 'Strategic alliance structuring: A game theoretic and transaction cost examination of interfirm cooperation', Academy of Management Journal 36: 794-829.

Rosen, R.J., Lloyd-Davies, P., Kwast, M.L. and Humphrey, D.B. (1989) 'New banking powers: A portfolio analysis of bank investment in real estate', Journal of Banking and Finance 13: 355-366.

Santomero, A.M. (1989) 'The changing structure of financial institutions', Journal of Monetary Economics 24: 321-328.

Santomero, A. and Chung, E. (1992) 'Evidence in support of broader bank powers', Financial Markets, Institutions and Instruments 1: 1-69.

Santomero, A.M. and Eckles, D.L. (2000) 'The determinants of success in the new financial services environment: Now that firms can do everything, what should they do and why should regulators care?', Federal Reserve Bank of New York Economic Policy Review (October): 11-23.

Saunders, A. (1994) 'Banking and Commerce: An overview of the public policy issues', Journal of Banking and Finance 18: 231-254.

Saunders, A. and Cornett, M.M. (2005) Financial Institutions Management: A Risk Management Approach, New York: McGraw-Hill.

Saunders, A. and Walter, I. (1994) Universal Banking in the United States: What Could we Gain? What Could we Lose?, New York: Oxford University Press.

Staikouras, S.K. (2005) The Greek Bank-Insurance Corporate Model: A Look at a Not-So-New Structure,working paper, Cass Business School, City University, London.

Staikouras, S.K. and Dickinson, G.M. (2005) An Examination of the Bank Incursion into Insurance Business: The Case of Greece, paper presented at the 12th Multinational Finance Society Conference, Athens, Greece.

Staikouras, S.K. and Kalotychou, E. (2005) De facto versus de jure bank-insurance ventures in the Greek market, working paper, Cass Business School, City University, London.

Sudarsanam, S. (1995) The Essence of Mergers and Acquisitions, London: Prentice Hall.

Van den Berghe, L. (1998) 'Shaping the future for the insurance sector', The Geneva Papers on Risk and Insurance 23: 506-518.

Van den Berghe, L. and Verweire, K. (1998) Creating the Future with all Finance and Financial Conglomerates, Dordrecht: Kluwer Academic Publishers. 
Van den Berghe, L. and Verweire, K. (2001) 'Convergence in the financial services industry', The Geneva Papers on Risk and Insurance 26: 173-183.

Van den Berghe, L., Verweire, K. and Carchon, S. (1999) Convergence in the Financial Services Industry, Report written under the authority of the OECD, September.

Vander Vennet, R. (2002) 'Cost and profit efficiency of financial conglomerates and universal banks in Europe', Journal of Money, Credit and Banking 34: 254-282.

Wall, L.D. (1987) 'Has bank holding companies' diversification affected their risk of failure?', Journal of Economics and Business 39: 313-326.

\section{Appendix A}

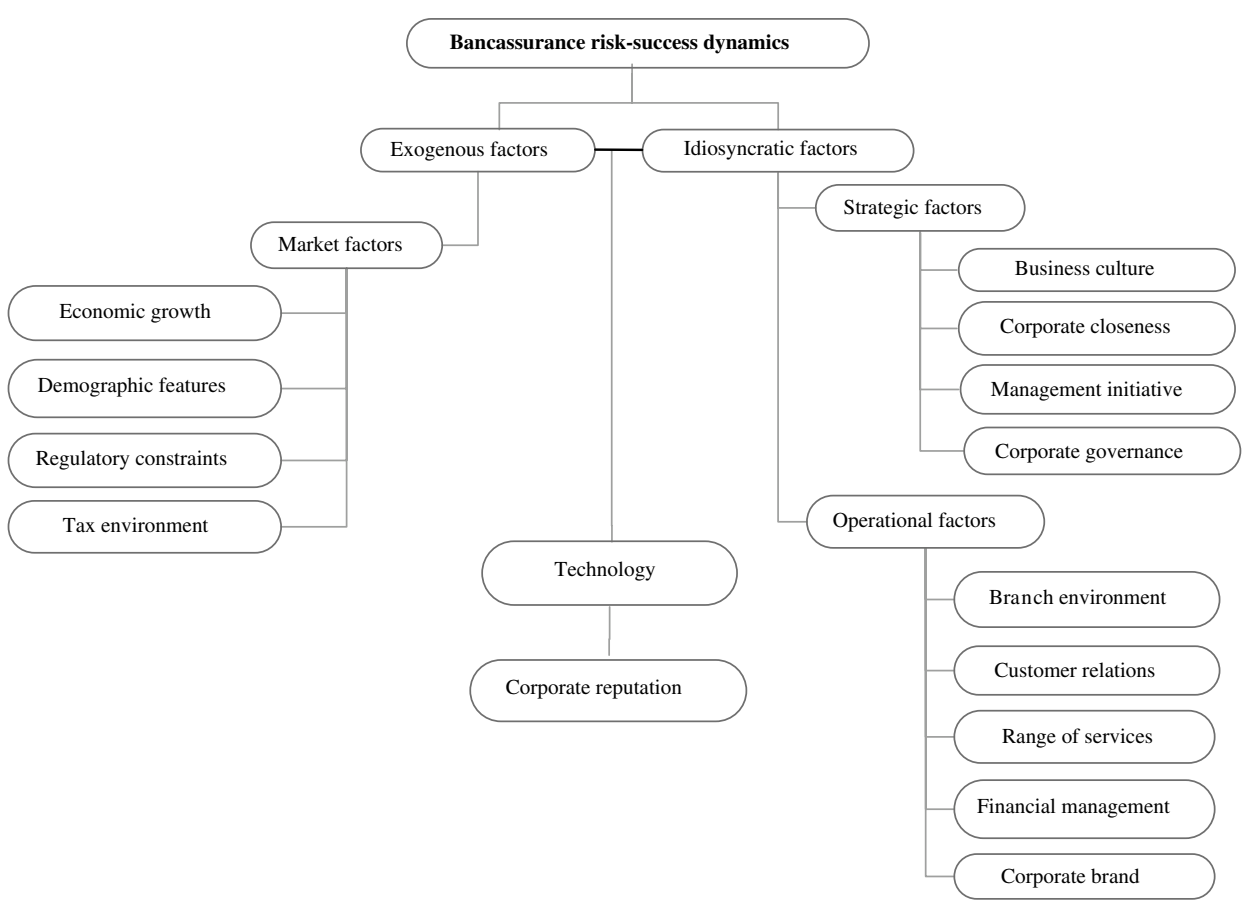

\section{About the Author}

Sotiris K. Staikouras currently serves as an associate professor of finance at Cass Business School, City University, London. His major research interests are risk analysis and management of financial institutions, asset pricing and financial modelling. Dr Staikouras has worked as a research advisor at London Clearing House and as financial analyst for other institutions. He holds a Ph.D. degree in finance from Cass Business School, and his research has been published in U.S. and European journals. 